\title{
GRAPEVINE LEAF WATER POTENTIAL BASED UPON NEAR INFRARED SPECTROSCOPY
}

\author{
Antonio Odair Santos ${ }^{1 *}$; Oren Kaye ${ }^{2}$ \\ ${ }^{1}$ IAC/Centro de Engenharia e Automação, C.P. 26 - 13201-970 - Jundiai, SP - Brasil. \\ ${ }^{2}$ Constellation Wines, 12667 Road 24, Madera, CA 93637, USA \\ *Corresponding author <odairsan@iac.sp.gov.br>
}

\begin{abstract}
Leaf water potential is a measure commonly used to describe crop water status and water stress dynamics. The established method for determining leaf water potential using a pressure chamber is cumbersome and subject to operator error as well as time/temperature limitations. These limitations prohibit the intensive sampling required to support proactive water management of commercial crops, including vineyards. Particular for grapevines there is need for faster, more precise and more reliable tools for determining leaf water potential in the field. Portable Near-infrared spectroscopy and multivariate data analysis were applied for the modeling and prediction of leaf water potential in grapevines. For field-grown wine grapes the most significant and intensive leaf absorptions occurs in the region from 1440 to $1950 \mathrm{~nm}$ and again beyond 2,200 $\mathrm{nm}$. Multivariate analysis of these spectra, referenced against pressure chamber measurements as a standard, showed correlation coefficients from 0.87 to 0.95 clearly demonstrated that this technology can provide a fast and reasonable assessment of leaf water potential in the field.
\end{abstract}

Key words: PLS, irrigation, spectrometry, chemometrics

\section{POTENCIAL DA ÁGUA NA FOLHA EM VIDEIRA COM BASE EM ESPECTROSCOPIA NO INFRAVERMELHO PRÓXIMO}

\begin{abstract}
RESUMO: O potencial da água na folha é um parâmetro amplamente utilizado para descrever o estado hídrico e a dinâmica do estresse hídrico de culturas de interesse agrícola, onde se inclui a videira vinífera. Um dos métodos correntes para determinação do potencial da água na folha é a câmara de pressão, que é complexa, sujeita a erros operacionais, possuindo limitações no preparo da amostra ligados ao tempo/temperatura. As limitações citadas dificultam amostragens intensivas requeridas para subsidiar estratégias de manejo mais avançadas em cultivos comerciais, como vinhedos. Portanto, há carência de instrumentação que ofereça maior rapidez de leitura, precisão e confiabilidade para a determinação do potencial da água na folha. Espectroscopia "portátil", operando na faixa do infravermelho-próximo e análise multivariada foi aplicada para a modelagem e simulação do potencial da água na folha de videira vinífera. Para videira vinífera de campo, a absorção mais intensiva e significativa da folha ocorre na faixa entre 1.440 e $1.950 \mathrm{~nm}$ e acima de $2.200 \mathrm{~nm}$. Análise multivariada espectral referenciada contra medições da câmara de pressão evidenciou coeficientes de correlação de 0.87 a 0.95 , claramente demonstrando que esta tecnologia pode proporcionar maior velocidade de aquisição e determinações razoáveis para dados de potencial da água na folha, em campo.

Palavras-chave: PLS, irrigação, espectrometria, quimiometria
\end{abstract}

\section{INTRODUCTION}

Measurement and knowledge of plant water relations is required to understand the interactions between the plant and the surrounding environment. Water potential gradients help to explain the water flux in the soil-plant-atmosphere continuum. In spite of diurnal fluctuations, leaf water potential can be used to describe the plant water status and as an indicator of overall plant water stress (Hsiao, 1973; Tardieu \& Katerji, 1990; Rana et al., 2004).
For grapevines, leaf water potential has been used for irrigation scheduling by Wample et al. (2005) and Deloire et al. (2005), among others. Leaf water potential measurements have been made primarily using the pressure chamber technique (Schollander et al., 1965). In spite of the many positive aspects of the pressure chamber, its usage in the field has the disadvantages of being invasive, demanding hermetical handling, and of being time consuming.

During recent years, developments in spectroscopic instrumentation and chemometric software 
have made it possible to rapidly perform multivariate analyses, correlating spectral data with quantitative chemical data. These developments have led the way for a much broader use of spectroscopy such as an accurate predictor of chemical concentrations of substances within a wide range of media (Wold et al., 2001; Martens \& Naes, 1983). In particular, NIR-based instrumentation has been used in a variety of agricultural areas, including viticulture and enology (Cozzolino et al., 2003; Kaye \& Wample, 2005)

Since water typically constitutes over $80 \%$ of the mass of plant tissues, it is expected that changes in water content would result in changes in its spectral characteristics. This supports the authors' hypothesis that the $\mathrm{O}-\mathrm{H}$ vibration of water should exhibit a detectable and quantifiable absorption in the NIR region. Therefore, the objective of this work was to predict the leaf water potential for field grown grapevines, using miniaturized portable NIR-based instrumentation and multivariate analysis.

\section{MATERIAL AND METHODS}

\section{Vineyards}

The data for leaf water potential modeling was acquired from Syrah, Merlot and Cabernet Sauvignon grapevines cultivated in vineyards transversing Californian's San Joaquin Valley (SJV) $\left(36^{\circ} 45^{\prime} \mathrm{N}\right.$, $119^{\circ} 45^{\prime} \mathrm{W}$ ), during the 2005 growing season. The data was gathered from berry set until véraison. The SJV is characterized by hot and dry summers with a persistently high vapor pressure deficit throughout the growing season and most of the rain occurring in winter. It is framed as BWk, following the Koeppen climatic classification (Critchfield, 1983). In the California classification system it is in Region V, signifying the highest possible number of Growing Degree Days (GDD) per growing season (Winkler et al., 1974).

\section{NIR instrumentation}

Leaf samples were analyzed using a (portable) handheld NIR instrument trademarked as Le Vigneron, Luminar 5030 system (Brimrose Corp, MD, USA). The system's NIR monochromatic beams were generated based upon Acoustic-Tunable-Optic-Filter (ATOF) technology (Workman \& Burns, 2001). AOTF uses sound waves to vibrate an acoustically sensitive crystal inside the spectrometer. The vibrating crystal precisely fractionates a light source into specific wavelengths. Those wavelengths can then be focused upon a surface. NIR spectral reflectance can then be measured and expressed as transmittance.

The spectral range used was 1,100 to $2,300 \mathrm{~nm}$ in transmission mode, with a wavelength increment of
$2 \mathrm{~nm}$. The signal to noise ratio was increased by scanning this spectral range 100 times per measurement and averaging all the acquired spectra. After acquisition, the spectral data was converted to absorbance $(\log (1 / \mathrm{T}))$, the logarithm of the reciprocal of transmission.

\section{Laboratory Experimentation}

In order to develop a standardized procedure for NIR applications in the field, laboratory experimentation preceded field testing of the instrument. In a first attempt to calibrate the NIR instrument for grapevine leaf water potential predictions, shoots of Cabernet Sauvignon and Thompson Seedless were gathered randomly from a vineyard. Their 'in-field' leaf water status was maintained by submerging the cut end of the shoots in a large bucket of water and enveloping the entire shoot in a closed plastic bag. With the shoot end still submerged in water, holes were torn in the plastic to allow for spectral analysis of the leaves. The NIR spectra were acquired from only the bottom side of the leaves just prior excision from the shoots. As the NIR beam will penetrate beyond the thickness of the leaf tissue, an NIR-neutral surface was placed on the opposite side of the leaf. 15-20 spectra on average were collected from multiple interveinal positions in a random pattern from the underside of each leaf. The number of spectra collected was determined by the leaf relative size and durability. No less than ten spectra were collected from any leaf in the data set. No more than 25 spectra were collected from any leaf as to not fatigue the leaf's tissue. Only 3-5 leaves were examined per shoot because the excessive contursions of the excised shoots was too damaging to the remaining leaves on the shoot.

Immediately after the NIR spectra were collected, the leaves were analyzed in a pressure chamber as per the protocol detailed by Boyer (1967). Leaves were bagged in small plastic bags and cut from the shoot with a razor blade before being placed in the pressure chamber.

For $30 \%$ of this sample set, subsequent to pressure chamber analysis each leaf was weighed and allowed to dehydrate by leaving it exposed at room temperature. The amount of dehydration was determined by weight loss. As much as $1-3 \%$ of the leaf water mass was allowed to escape. Thereafter the leaf was reanalyzed by NIR and pressure chamber in the same manner as previously stated. This allowed for calibration using marked changes in leaf water potential. All of the leaf spectra associated with any given pressure chamber value were averaged together to account for localized differences in water potential across each leaf. In total 103 averaged values were derived from more than 1600 usable spectra across the entire data set. 


\section{Vineyard Testing}

To perform vineyard testing of the NIR over a large area, the NIR was equipped with a battery pack and transported on the front end of an all-terrain vehicle (ATV). "On-the-go" measurements of Syrah, Merlot and Cabernet Sauvignon varietals were made in vineyards from Livingston, CA, to Delano, CA.

Approximately 904 spectra were acquired using the same procedure for scanning as described above. Vines were randomly selected within each vineyard and three leaves were scanned per plant. Midcanopy leaves with sun speckling were chosen for the NIR analysis, as these leaves were thought to be most representative of the overall water dynamics in the vine. Notably, this was a deliberate departure from the procedural limitations of standard pressure chamber techniques, in contrast to the requirements of using fully exposed leaves at solar noon; the authors reasoned that in the SJV arid conditions, partially exposed leaves were more likely to be photosynthetically active than fully exposed leaves. Additionally, under most canopy conditions, partially exposed leaves should greatly out number fully exposed leaves. According to such examining, three partially exposed leaves should give a much greater indication of the overall health and water status of a vine than leaves which are temporarily at their maximum stress and photosynthetically inactive.

The scanning consisted of three readings ( 21 s) for each leaf. After being scanned, the leaves were wrapped in plastic bags, excised from the shoot, and placed in an insulated cooler over ice. The leaf water potential was then read at the first opportunity using a pressure chamber, according to methodology previously described in Boyer (1967). All leaves were examined from late June to early August, corresponding physiologically to the growth phase between berry set and véraison.

\section{Chemometrics and data analysis}

Acquisition and transformation of all spectral data was processed using Brimrose Snap 2.04 ${ }^{\mathbb{B}}$ software (MD, USA). Chemometric analysis and statistical interpolation of the transformed spectra was accomplished using CAMO Unscramble $8.0^{\circledR}$ software (Norway).

Calibrations were developed using partial least square regression (PLS) with internal cross validation. PLS is a multiregressional technique that can relate the variation in one or several variables (in this case LWP, $y$-data) to the variation of several predictors (contained in the spectra, $x$-data) for descriptive or predictive purposes. The information in the original $\mathrm{x}$-data is projected onto a small number of underlying ("latent") variables called PLS components (PC's). The y-data are actively used in estimating the "latent" variables to ensure that the first components used are those which are most significant for predicting the y-variable (Svante et al., 1983; Martens \& Naes, 1983).

Full cross-validation was used to estimate the prediction error by splitting all samples into groups. One group was reserved for calibration and the remaining groups used for validation. The process was repeated until all groups were used for validation at least once. The performances of the models were then verified by (i) the models' overall correlation coefficients (CC), (ii) the standard error of calibration (SEC), and (iii) the standard error of cross-validation (SECV). The best calibration model was selected based on the minimum SECV.

Separate models were created for the lab and vineyard data sets because of procedural differences due to the circumstance of data collection in a laboratory and vineyard environment. Additionally, the data sets were kept separate because of distinct differences in the patterns of spectral inflections between the two data sets. For the laboratory experiment, the first derivative of the absorbance data was needed to obtain the best model for prediction. For the field tests, no pre-treatments were needed to obtain the best models for calibration development.

For the vineyard tests, a combined model (SMCs) was created for the cultivars Syrah (S), Merlot (M) and Cabernet Sauvignon (Cs). Also, to further explore variety-specific trends, an additional model was created which examined LWP just in the cultivar Cabernet Sauvignon. This Cs model included spectra from the SMCs model and spectra from other Cs leaves sampled during a wider expanse of the growing season.

\section{RESULTS AND DISCUSSION}

Individual LWP models were created for Syrah, Merlot and Cabernet Sauvignon, with NIR spectragraphs containing 904 averaged spectra for these calibrations (Figure 1). The main features of these spectra are distinguished by vibrational indicators at the 1450 and $1930 \mathrm{~nm}$ bands. These are very similar to the vibrational bond characterization for pure water in the NIR region as described by Shenk et al. (2001). In other agricultural products, these bands have corresponded to the first overtone of the $\mathrm{O}-\mathrm{H}$ excitation for $\mathrm{H}_{2} \mathrm{O}$ and the combination of O-H and $\mathrm{H}-\mathrm{O}-\mathrm{H}$ deformation, respectively (Shenk et al., 2001). As such, we can assume with confidence that water within leaf tissue is also represented by these inflections and not overlapped by inflections from other cell constituents 
such as starch and cellulose (C-H bonds), that can also be measured with NIR. In fact, further studies of the matter (Shenk et al., 2001; Workman \& Shenk, 2004) have lead the authors to speculate that the "up-turn" in absorbance beyond 2,200 nm (Figure 1) corresponds to the $\mathrm{C}-\mathrm{H}$ bond vibrations characteristic of starch, cellulose or protein.

The variation in the amplitude of the profiles shown for $\mathrm{O}-\mathrm{H}$ bonds (water) and $\mathrm{C}-\mathrm{H}$ bonds (cellulose, starch, protein, etc) in the Figure1 represent the combined variation in the water potential found in the vineyard test for these three cultivars. As discussed by Shenk \& Workman (2004) the NIR spectrum is unique for each and every biological substance, much as fingerprints distinguish humans. The correlation and validation coefficients determined for combined SMCs model (Figure 2) indicate that the correlation coefficient for the calibration is 0.87 which is reasonable considering the data was obtained in the field. The near-overlap of the correlation and validation projections indicates that the model can be extrapolated to predict LWP over a wide range.

The number of components needed to explain the leaf water potential variability was approximately 10 (Table 1). However, three components were sufficient to explain most of the variance in the spectra (xvariable) (Figure 3). This type of reduction is expected in a PLS regression model, since for a set of data with reasonable correlation the first components carry most of the variance. For the rest of the modeled groups ( $\mathrm{Lab}$ and: $\mathrm{Cs}$ ) the performance is shown in Table 1. In general, the calibrated models, Cs and the Lab models, presented good prediction ability. All the correlation coefficients were higher than 0.80 and the values in the bias were close to zero, revealing low probability of systematic error.

When comparing the modeling approaches, the Cs model performed better than both the lab model and the SMCs model in spite of the small number of scans used per leaf. It also yielded smaller values for SEC and SECV. This revealed that the data for Cs was less random and less projected PLS components were necessary to account for the variance to decrease the standard error of prediction to the minimum value (Table 1). From this we can interpret that we may be benefited by using less scans per leaf when predicting LWP. Physical variations across the leaf and abnormal excitation from repeated NIR scanning may have contributed to higher levels of background noise in the lab and SMCs models. This was further verified by the need to have used the first derivative of the absorbance values to compute the best calibration for the lab model. The first derivative transformation is commonly used to reduce background noise in statistical computations. Because of the excessive scanning used in the laboratory ex-

Table 1 - Descriptive statistics for the calibration models for wine grape leaf water potential, during the growing season of 2005.

\begin{tabular}{lcccccc}
\hline Models Source & Averaged Samples & PLS Components & Calibration Coefficient & SEC & SECV & BIAS \\
\hline Lab & 103 & 7 & 0.84 & 1.99 & 1.98 & 0.0000017 \\
Field: SMCs & 906 & 10 & 0.87 & 1.49 & 1.48 & 0.00000047 \\
Field: Cs & 359 & 4 & 0.95 & 1.09 & 1.08 & 0.00000039 \\
\hline
\end{tabular}

SEC: Standard error of calibration; SECV: Standard error of cross-validation

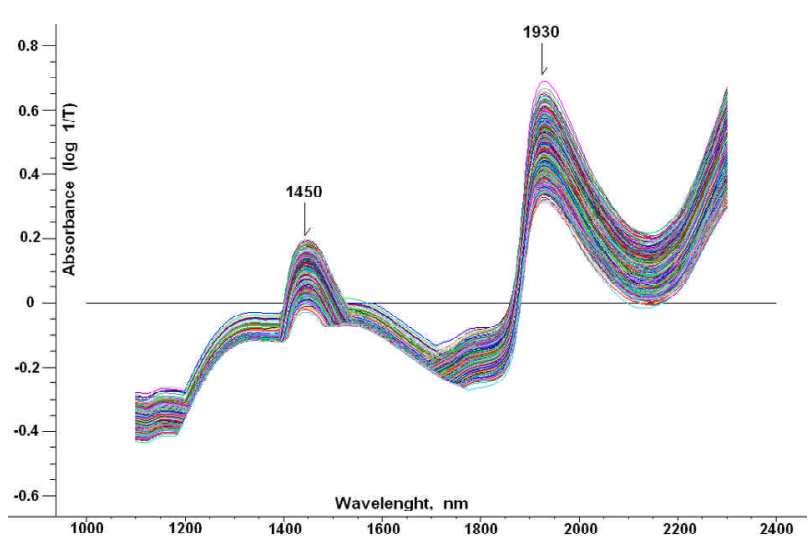

Figure 1 - Near-infrared spectra of leaves collected from Syrah, Merlot and Cabernet Sauvignon cultivars. $\mathrm{T}=$ transmission.

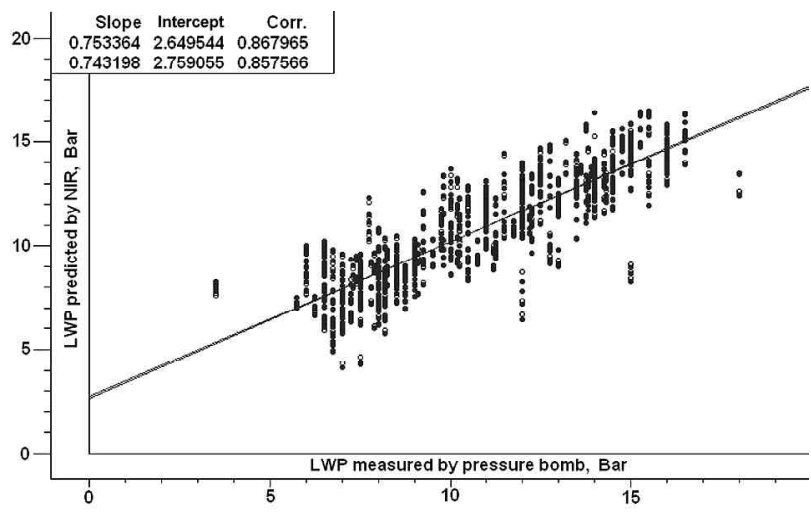

Figure 2 - Actual versus predicted leaf water potential (LWP) in leaves of syrah, merlot and cabernet sauvignon (SMCs model). Corr.: Correlation and validation coefficients for the first and second line, respectively. 


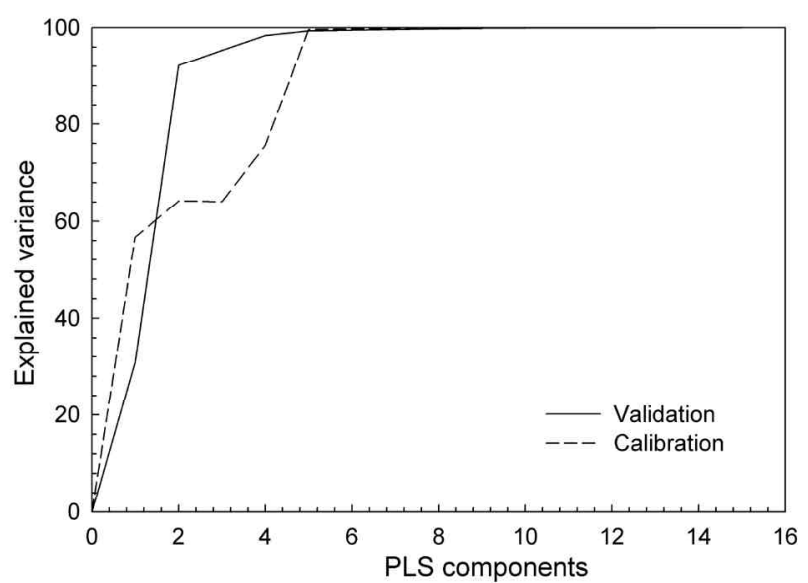

Figure 3 - Explained variance for calibration and validation for sample leaves of Syrah, Merlot and Cabernet Sauvignon in the 2005 growing season (SMCs).

periment (15-20 spectra per leaf), we may have oversaturated the system with background noise whereby requiring the first derivative to attenuate the interpretation of spectral data.

Other seasonal and procedural differences between the lab experiment and field tests may account for the differences in their spectral-graphs. The lack of stretching and deformation beyond 2,200 $\mathrm{nm}$ in the lab model might be explained by the differences in age of the measured leaves, as the lab portion of the experiment preceded the field test by more than 30 days. Additionally, shoots for the lab model were collected over the entire course of a day (over 3-days) as opposed to the field tests which occurred only from midmornings to mid-afternoons. It is possible that variations in the leaf starch content (representative of various phases of starch exportation from the leaf) across the day may have depleted the quantity of measurable $\mathrm{C}-\mathrm{H}$ constituents in the leaf, mitigating the NIR signal in the 2,200 $\mathrm{nm}$ region. Other spectral differences between the lab and field test included a shift in the peaked interval for LWP corresponding to 1500 and $1700 \mathrm{~nm}$ respectively for the lab model. This shift can again be explained be seasonal, procedural or environmental differences in the experiment. As physical and biochemical changes occur in leaf tissue as the season progresses, corresponding changes in light scatter from NIR excitation can be expected.

Figure 4 may help to provide some further interpretation of the main differences between the three models. The first PLS loadings for all models represents the most significant points of variation between the spectra. The loading for the first component is characterized by the peaks (up and down) coinciding to the overtones and stretch/combination bands of O$\mathrm{H}$ in the region of 1,430 and $1,950 \mathrm{~nm}$, as previously described in Figure 1 for the two field tested models.

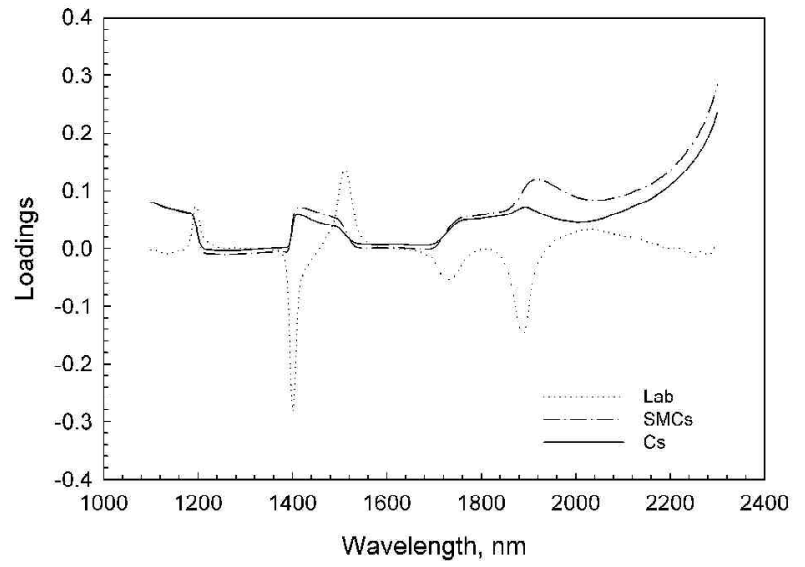

Figure 4 - The first PLS loading for the three calibrations performed in winegrapes, during the 2005 growing season.

All models except for the Lab model, also have C-H stretching/deformation in the bands beyond 2,200 nm. The similarities between the loadings for Cs and SMCs models, suggest major consistencies exist between the two data sets. As water is the overwhelming constituent in all grape leaf tissue, it stands to reason that water should be consistently quantified in the same NIR regions.

The slight variations between the loadings for the two field models may be indicative of minor physiological differences between leaves associated with cultivar or varying levels of environmental stress.

\section{CONCLUSIONS}

The lab and field tests have demonstrated that the NIR technology can be used to quantify LWP respective to pressure chamber as the standard reference for this measure. As LWP is in constant flux, questions remain as to the best benchmark for assessing vine water status in the soil-plant-atmosphere continuum. The speed and flexibility of NIR offers a wide range of possibilities to answer these questions. Further research extending the use of NIR is likely to provide a paradigm shift in the way we consider these critical variables.

Analysis of spectra collected demonstrated wavelengths shifts at $1440 \mathrm{~nm}, 1950 \mathrm{~nm}$ and beyond $2,200 \mathrm{~nm}$ when examining leaf tissue in the field. PLS analysis has provided evidence that the $1,440 \mathrm{~nm}$ and $1,950 \mathrm{~nm}$ portion of the spectra was used to quantify LWP. Further researchs are needed to determine the nature of the spectral inflections beyond 2,200 $\mathrm{nm}$.

The best predictive models for leaf water potential were found to be variety-specific. Our data has also indicated that separate calibration may need to be derived for the various phases of leaf maturity. 


\section{REFERENCES}

BOYER, J.S. Leaf water potential measured with a pressure chamber. Plant Physiology, v.42, p.213-217, 1967.

COZZOLINO, D.; KWIATKOWSKI, M.J.; PARKER, M.; CYNKAR, W.U.; DAMBERGS, R.G.; GISHEN, M.; HERDERICH, M.J. Prediction of phenolic compounds in red wine fermentations by visible and near infrared spectroscopy. Analytica chimica Acta, v.513, p.73-80, 2004.

CRITCHFIELD, H.J. General climatology. 4 ed. Englewood Cliffs: Prentice-Hall, 1983. 453p.

DELOIRE, A.; OJEDA, H.; ZEBIC, O.; BERNARD, N.; HUNTER, J.J.; CARBONEAU, A. Influence de l'etat hydrique de la vigne sur le style de vin. Progres Agricole et Viticole, v.122, p.455462, 2005.

HSIAO, T.C. Plant responses to water stress. Annual Review of Plant Physiology, v.24, p.519-570, 1973.

KAYE, O.; WAMPLE, R.L. Using Near-infrared spectroscopy as an analytical tool in vineyards and wineries. In: ASEV ANNUAL CONFERENCE, 23, Seattle, 2005. Proceedings. Seattle: ASEV, 2005. p.47-49.

MARTENS, H.; NAES, T. Multivariate calibration. In: KOWALSKI, B.R. (Ed.) Chemometrics: mathematics and statistics in chemistry. Amsterdam: Kluwer, 1983. p.145-156.

RANA, G.; KATERJI, N.; INTRONA, M.; HAMMAMI, A. Microclimate and plant water relationship of the "overhead" table grape vineyard managed with three different covering techniques. Scientia Horticulturae, v.102, p.105-120, 2004.

SCHOLLANDER, R.F.; HAMELL, H.T.; BRADSTREET, E.D.; HEMMINGSEN, E.A. Sap pressure in vascular plants. Science, v.148, p.339-346, 1965.

SHENK, J.; WORKMAN, J.J.; WESTERHAUS, M.O. Application of NIR spectroscopy to agricultural products. In: BURNS, D.; CIURCZAK, E.W. (Ed.) Handbook of near-infrared analysis. New York: Marcel Dekker, 2001. p.419-474.
SVANTE, W.; ALBANO, C.; DUNN, W.J.; EDLUND, U.; ESBENSEN, P.; GELADI, S.; HELLBERG, E.; JOHANSSON, W.; LINDBERG, W.; SJOSTROM, M. Multivariate data analysis in chemistry. In: KOWALSKI, B.R. (Ed.) Chemometrics: mathematics and statistics in chemistry. Amsterdam: Kluwer, 1983. p.17-95.

TARDIEU, F.; KATERJI, N. Relations entre l'état hydrique du sol, le potentiel de base et d'autres indicateurs de la cointraint hydrique chez le mais. Agronomie, v.10, p.617-626, 1990.

WAMPLE, R.L.; WILLIANS, L.; ADAMS, D. Wine grape irrigation management in the San Joaquin Valley of California. In: SYMPOSIO INTERNATIONAL DEL MANEJO DE RIEGO Y SUELO EN VIDES PARA VINO Y MESA, 1., Santiago de Chile, 2005. Proceedings. Santiago de Chile: INIA, 2005. p.38-46.

WINKLER, A.J.; COOK, J.; KLIEWER, W.; LIDER, L. General viticulture. Berkeley: University of California Press, 1974. $270 \mathrm{p}$.

WOLD, S.; TRYGG, J.; BERGLUND, A.; ANTTI, H. Some recent developments in PLS modeling. Chemometrics and Intelligent Laboratory Systems, v.58, p.131-150, 2001.

WORKMAN-JR.; J.; BURNS, D.A. Comercial NIR instrumentation. In: BURNS, D.; CIURCZAK, E.W. (Ed.) Handbook of nearinfrared analysis. New York: Marcel Dekker, 2001. p.53-70.

WORKMAN-JR.; J.; SHENK, J. Understanding and using the NearInfrared spectrum as an analytical method. In: ROBERTS, C.A.; WORKMAN-JR., J.; REEVES-III, J.B. (Ed.) Near-infrared spectroscopy in agriculture. Madison: ASA, 2004. p.3-10.

WORKMAN-JR.; J. NIR Spectrophotometers. In: ROBERTS, C.A.; WORKMAN-Jr, J.; REEVES-III, J.B. (Ed.) Near-infrared spectroscopy in agriculture. Madison: ASA, 2004. p.11-48.

Received November 22, 2007

Accepted October 06, 2008 